Kumawula, Vol. 3, No.3, Desember 2020, Hal 441 - 448 DOI: https://doi.org/10.24198/kumawula.v3i3.28062

ISSN 2620-844X (online)

Tersedia online di http://jurnal.unpad.ac.id/kumawula/index

\title{
MODEL TATA KELOLA BADAN USAHA MILIK DESA (BUMDes) DI DESA LUMBUNGSARI KECAMATAN LUMBUNG KABUPATEN CIAMIS
}

\author{
Engkus $^{1^{*}}$, Fadjar Tri Sakti ${ }^{2}$, Nanang Suparman ${ }^{3}$ \\ ${ }^{1}$ UIN Sunan Gunung Djati Bandung Indonesia \\ ${ }^{2}$ UIN Sunan Gunung Djati Bandung Indonesia \\ ${ }^{3}$ UIN Sunan Gunung Djati Bandung Indonesia \\ *Korespondensi : engkus@uinsgd.ac.id
}

\begin{abstract}
ABSTRAK
Pemerintah Desa Lumbungsari membentuk Badan Usaha Milik Desa (BUMDes) Harapan Jaya dalam rangka meningkatkan Pendapatan Asli Desa (PADes) serta melakukan pemberdayaan masyarakat. Tetapi dalam pelaksanaannya masih terdapat hambatan seperti kurangnya sosialisasi kepada masyarakat secara menyeluruh, luasnya wilayah, dan petugas serta kompetensi pengelola BUMDes masih terbatas. Tujuan penelitian ini adalah untuk mendeskripsikan implementasi program Badan Usaha Milik Desa (BUMDes) di Desa Lumbungsari Kecamatan Lumbung Kabupaten Ciamis. Penelitian ini menggunakan pendekatan kualitatif deskriptif, dengan menerapkan teori A Model of the Policy Implementation oleh Donald van Metter dan Carl van Horn. Teknik pengumpulan data yang digunakan adalah observasi, wawancara serta studi dokumentasi. Teknik pemilihan informan menggunakan teknik purposive sampling. Hasil penelitian menunjukkan bahwa implementasi program BUMDes belum optimal.
\end{abstract}

Kata kunci: Model Tata Kelola , kebijakan, BUMDes.

\section{MODEL FOR MANAGEMENT OF VILLAGE BUSINESS ENTITIES (BUMDES) IN LUMBUNGSARI VILLAGE, LUMBUNG SUB-DISTRICT CIAMIS REGENCY}

\begin{abstract}
The Lumbungsari Village Government formed the Harapan Jaya Village-Owned Enterprise (BUMDes) in order to increase the Village Original Income (PADes) and carry out community empowerment. But in its implementation, there are still obstacles such as the lack of socialization to the community as a whole, the size of the area, and the officers and competencies of the BUMDes managers are still limited. The purpose of this study was to describe the implementation of the Village-Owned Enterprise (BUMDes) program in Lumbungsari Village, Lumbung District, Ciamis Regency. This study used a descriptive qualitative approach, applying the theory of A Model of the Policy Implementation by Donald van Metter and Carl van Horn. The data collection techniques used were observation, interview and documentation study. The technique of selecting informants using a purposive sampling technique. The results showed that the implementation of the BUMDes program was not optimal.
\end{abstract}

Keywords: Governance Model, policy, BUMDes.

\section{PENDAHULUAN}

Otonomi di Indonesia lahir akibat adanya perubahan tatakelola pemerintahan dari sentralistis menjadi terdesentralisasi (Widianingsih, Setiawan, \& Chuddin, 2020).
Otonomi yang berjalan di Indonesia tidak hanya bagi daerah yang memiliki otonomi daerah, tetapi desa juga memiliki otonomi desa di mana desa memiliki hak dan kewenangan penuh dalam mengelola pemerintahannya sendiri secara mandiri dan kreatif dalam meningkatkan 
kemajuan dan kesajahteraan masyarakat desa. Kebijakan ini pertama kali diatur dalam UU No. 32 Tahun 2004 tentang Pemerintahan Daerah terakhir diubah menjadi Undang-Undang Nomor 9 Tahun 2015. Seiring berjalannya waktu, Undang-undang tersebut mengalami perubahan menyesuaikan dengan keadaan yang terjadi, hingga akhirnya pemerintah terdorong untuk mengeluarkan undang-undang tentang Desa.

Sebagai daerah yang memiliki otonomi penuh, desa harus mencari dana sendiri untuk mengembangkan desanya. Meski sekarang terdapat peraturan yang menyatakan bahwa desa di setiap tahunnya akan mendapatkan bantuan dari APBN sekitar 600 juta hingga 1,2 milyar rupiah yang tercantum dalam UU No. 6 Tahun 2014 Pasal 72 ayat (1) dan (4), tetapi desa tidak bisa sepenuhnya menggantungkan pemasukkannya dari bantuan tersebut. Pemerintah desa harus menggali potensi desa baik dari segi Sumber Daya Alam (SDA) maupun dari segi Sumber Daya Manusia (SDM) yang ada di desa tersebut yang nantinya akan menjadi sumber pendapatan desa dan akan masuk ke dalam kas desa.

Salah satu strategi yang dilakukan pemerintah untuk dapat meningkatkan perekonomian desa adalah dengan mendirikan Badan Usaha Milik Desa (BUMDes) (Senjani, 2019). Pendirian BUMDes ini kemudian diatur dalam UU No. 32 Tahun 2004 Pasal 213 yang menyebutkan bahwa pemerintah desa dianjurkan untuk memiliki Badan Usaha Milik Desa (BUMDes) yang berguna untuk mengatur perekonomian dan menggali potensi desa. BUMDes merupakan salah satu lembaga yang di dalamnya terdapat interaksi ekonomi antara pemerintah desa dengan masyarakat desa, sehingga hal ini juga berdampak pada hubungan antara pemerintah desa dengan masyarakat yang akan tercipta secara alamiah.

Desa Lumbungsari merupakan salah satu desa yang berada di Kecamatan Lumbung Kabupaten Ciamis. Desa ini memiliki BUMDes bernama Harapan Jaya yang dibentuk pada tanggal 22 Juli 2016 yang dimuat dalam
Peraturan Desa Lumbungsari No. 6 Tahun 2016 tentang Badan Usaha Milik Desa (BUMDesa).

Pada awal pembentukkan, BUMDes Harapan Jaya menempati bangunan yang statusnya bukan milik sendiri dan memiliki 4 (empat) program utama kegiatan yang dijalankan diantaranya adalah Unit Saprotan/ penyedia pupuk, Unit Waserda, Unit Laku Pandai, dan Unit Bank Sampah. Selama beberapa bulan dijalankan program-program tersebut bisa dikatakan berjalan dengan cukup baik, namun salah satunya yaitu Unit Bank Sampah selalu mengalami hambatan dan kendala sehingga tidak dapat berjalan dengan baik, dan pada akhirnya BUMDes Harapan Jaya memutuskan untuk berhenti menjalankan Unit Bank Sampah ini, karena keterbatasan sumber daya, baik sumber daya manusia maupun sumber daya yang lainnya.

Selama pelaksanaan dalam masingmasing program unit usaha, memiliki hambatan tersendiri. Seperti misalnya, Unit Saprotan atau "Sarana Produksi Pertanian”, menjalankan kegiatan yang bergerak dalam bidang penyediaan sarana produksi pertanian terutama pupuk untuk memenuhi kebutuhan para petani khususnya di sekitar wilayah Desa Lumbungsari. Lokasi kegiatan Unit Saprotan ini bertempat di Dusun Cileungsing yang berjarak sekitar satu kilometer dari kantor sekretariat BUMDes Harapan Jaya. Hal ini menjadi kendala dan alasan bagi sebagian masyarakat Desa Lumbungsari mengapa mereka tidak membeli pupuk dan kebutuhan pertanian lainnya di Unit Saprotan BUMDes ini. Masyarakat lebih memilih untuk membeli pupuk di warung atau kios-kios yang juga menjual pupuk yang terdapat di dusunnya masing-masing.

Selain Unit Saprotan, BUMDes Harapan Jaya juga menjalankan Unit Waserda. Unit Waserda atau "warung serba ada" ini bergerak dalam bidang pelayanan masyarakat dalam hal pemenuhan kebutuhan sehari-hari dan sembako. Lokasi operasional, dalam unit ini juga menjadi kendala dalam pelaksanaannya, di mana lokasinya berada di Dusun Dayeuhdatar, 
yang juga berjarak sekitar satu kilometer dari Balai Desa atau pusat sekretariat BUMDes.

BUMDes Harapan Jaya juga memiliki Unit Laku Pandai. Unit Laku Pandai adalah salah satu unit usaha BUMDes Harapan Jaya yang menjalankan kegiatan dalam hal pelayanan kepada masyarakat dalam penyediaan Alat Tulis Kantor, jasa foto kopi, dan yang baru direalisasikan adalah jasa keuangan, di mana memfasilitasi masyarakat yang ingin melakukan berbagai macam transaksi keuangan, seperti men-transfer uang, pembayaran listrik PLN, membeli tiket kereta api, tiket pesawat, dan sebagainya.

Setelah BUMDes Harapan Jaya ini dibentuk, masyarakat masih kurang berpartisipasi dalam berjalannya BUMDes tersebut. Bahkan bukan tidak mungkin, masyarakat belum mengetahui keberadaan BUMDes di desanya sendiri. Padahal jika masyarakat mengetahui tujuan dari pendirian BUMDes bisa sangat membantu dan menguntungkan, sebagaimana tercantum dalam Permendes PDTT Nomor 4 Tahun 2015. Layanan BUMDes mencakup luas wilayah 483 ha, yang terdiri dari 9 Dusun, dengan jangkauan penduduk 1161 Kepala Keluarga, 3218 jiwa yang terdiri dari 1537 orang laki-laki, serta 1681 orang perempuan. (http://cahayapenge-tahuan.blogspot.com/2014/07/profil-desalumbung.html).

Peran pemerintah daerah juga sangat penting untuk kemajuan BUMDes ini, dalam Permendagri 39 Tahun 2010 pasal 22 ayat (1) dan ayat (2) menyebutkan bahwa pemerintah daerah baik itu pemerintah provinsi maupun pemerintah kabupaten/kota harus melakukan sosialisasi, pembinaan, bimbingan teknis, pengembangan manajeman dan sumber daya manusia serta memberikan fasilitas akselerasi permodalan. Namun, berdasarkan wawancara yang peneliti lakukan kepada Ketua BUMDes Harapan Jaya, Ajid Sajidin, ternyata peran pemerintah daerah masih belum begitu dirasakan oleh BUMDes Harapan Jaya.
Dalam penelitian ini, peneliti menggunakan kerangka berpikir untuk memudahkan dalam penelitian: (a) Landasan Hukum BUMDes: (1) UU Nomor 32 Tahun 2004 tentang Pemerintahan Daerah. (2 )UU Nomor 6 Tahun 2014 tentang Desa. (b) Permendagri Nomor 39 Tahun 2010 tentang Badan Usaha Milik Desa. (c) Perda Kabupaten Ciamis Nomor 26 Tahun 2013 tentang Pedoman Tata Cara Pembentukan dan Pengelolaan Badan Usaha Milik Desa.

\section{Implementasi Kebijakan}

Thomas Dye mengemukakan bahwa yang dimaksud dengan kebijakan publik adalah apapun yang pemerintah lakukan atau tidak lakukan (dalam Subarsono, 2005). Pada prinsipnya, implementasi kebijakan merupakan upaya yang dilakukan untuk mencapai tujuan kebijakan (Nugroho, 2003). Untuk mengukur tingkat keberhasilan implementasi kebijakan publik, Donald S. van Metter dan Carl E. van Horn (dalam Agustino, 2016: 133) merumuskan suatu model pendekatan yang dikenal dengan $A$ Model of the Policy Implementation. Terdapat enam variabel menurut Meter dan Horn, yang mempengaruhi kinerja kebijakan publik tersebut antara lain:

(a) Ukuran dan tujuan kebijakan; ukuran dan tujuan sebuah kebijakan harus jelas dan terukur, karena ketidakjelasan ukuran dan tujuan kebijakan berpotensi untuk menimbulkan multi-interpretasi yang akhirnya akan berimplikasi pada sulitnya implementasi kebijakan.

(b) Sumber daya; Implementasi kebijakan perlu dukungan sumber daya yang memadai, baik sumber daya manusia maupun sumber daya non-manusia. Dukungan sumber daya ini akan memengaruhi kinerja implementasi kebijakan. Kurangnya sumber daya akan menyulitkan implementasi kebijakan.

(c) Karakteristik agen pelaksana; adalah mencakup struktur birokrasi, normanorma, dan pola-pola hubungan yang 
terjadi dalam birokrasi, yang semuanya itu akan mempengaruhi implementasi kebijakan.

(d) Sikap atau kecenderungan para pelaksana: (1) Respon implementor terhadap kebijakan, yang akan mempengaruhi kemauannya untuk melaksanakan kebijakan; (2) Kognisi, yaitu pemahamannya terhadap kebijakan; dan (3) Intensitas kecenderungan implementor, yaitu preferensi nilai yang dimiliki oleh implementor.

(e) Komunikasi antar organisasi dan aktivitas pelaksana; Jalinan hubungan kerjasama yang sinergis diperlukan antar instansi terkait untuk mendukung keberhasilan implementasi kebijakan.

(f) Lingkungan ekonomi, sosial, dan politik, variabel ini mencakup sumber daya: ekonomi lingkungan yang dapat mendukung keberhasilan implementasi kebijakan; sejauh mana kelompok-kelompok kepentingan memberikan dukungan bagi implementasi kebijakan; karakteristik para partisipan, yakni mendukung atau menolak; bagaimana sifat opini publik yang ada di lingkungan; dan apakah elit politik mendukung implementasi kebijakan.

\section{Permasalahan:}

(1) Terlambatnya Pembentukan BUMDes di Desa Lumbungsari.

(2) Peran pemerintah daerah baik kabupaten atau provinsi masih kurang dalam mendukung pelaksanaan BUMDes di Desa Lumbungsari.

(3) Masyarakat kurang berpartisipasi dalam pelaksanaan BUMDes di Desa Lumbungsari.

(4) Keberadaan BUMDes di Desa Lumbungsari memiliki pengaruh yang kurang signifikan dalam pemberdayaan masyarakat.
Untuk mempermudah dalam penelitian, skema kerangka pemikiran sebagai berikut:

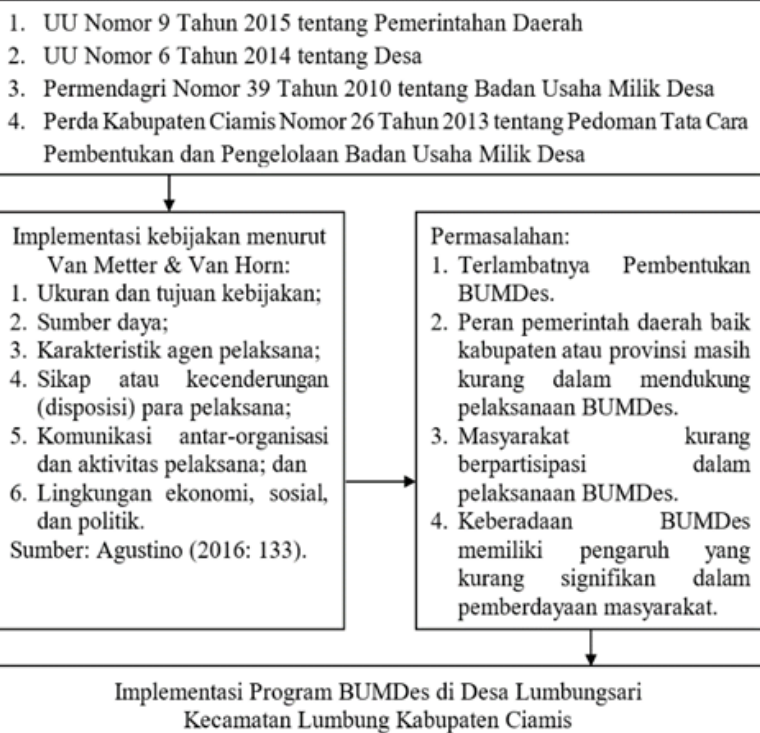

Implementasi Program BUMDes di Desa Lumbungsari Kecamatan Lumbung Kabupaten Ciamis

Sumber: Hasil penelitian (diolah peneliti), 2020

\section{DESAIN PENELITIAN}

Dalam penelitian ini, menggunakan metode penelitian kualitatif dengan pendekatan deskriptif, dengan maksud agar peneliti dapat menyelidiki objek penelitian sesuai dengan latar alamiah yang ada di lapangan. Metode ini juga digunakan karena peneliti berusaha mencari gambaran suatu kelompok dalam mencapai tujuan kelompok tersebut, sehingga dapat terungkap dengan jelas (Rachmawati, 2017).

Sugiyono (2012: 15) mengemukakan bahwa metode penelitian kualitatif adalah metode penelitian yang berlandaskan pada filsafat positivisme, digunakan untuk meneliti pada kondisi objek yang alamiah, (sebagai lawannya adalah eksperimen) dimana peneliti adalah sebagai instrumen kunci, pengambilan sampel sumber data dilakukan secara purposive dan snowball, teknik penggabungan dilakukan dengan triangulasi, analisis data bersifat induktif/kualitatif, dan hasil penelitian kualitatif lebih menekankan makna daripada generalisasi.

\section{HASIL DAN DISKUSI}

Awal mula pemerintah menganjurkan desa untuk membentuk Badan Usaha Milik Desa terdapat pada Bagain Kelima Pasal 213 UU No. 32 Tahun 2004 tentang Pemerintahan Daerah (terakhir Undang-Undang Nomor 9 
tahun 2015) yang menyebutkan bahwa desa dapat mendirikan badan usaha milik desa sesuai dengan kebutuhan dan potensi desa. Dari situ pula, pemerintah mengeluarkan UU No. 6 Tahun 2014 tentang Desa yang secara lebih rinci mengatur hal-hal yang ada di desa termasuk Keuangan Desa. Kemudian juga dikeluarkan Permendagri No. 39 Tahun 2010 yang mengatur lebih rinci tentang BUMDes. Di Kabupaten Ciamis sendiri memiliki Perda No. 26 Tahun 2013 tentang Tata Cara Pembentukkan dan Pengelolaan Badan Usaha Milik Desa. Inilah yang menjadi landasan hukum yang digunakan oleh Desa Lumbungsari dalam mendirikan BUMDes dengan mengeluarkan Peraturan Desa Lumbungsari No. 7 Tahun 2016 tentang BUMDes.

Pembahasan pertama adalah ukuran dan tujuan kebijakan. Berdasarkan penelitian, tujuan utama didirikannya BUMDes di Desa Lumbungsari adalah untuk meningkatkan Pendapatan Asli Desa. Dengan memanfaatkan potensi dan sumber daya yang tersedia di Desa Lumbungsari, pemerintah desa mendirikan BUMDes dengan harapan dapat menambah PAD sekaligus menyejahterakan masyarakat desa dengan menyediakan berbagai produk dan jasa yang masih kurang atau belum ada yang dibutuhkan oleh masyarakat.

Kedua adalah sumber daya. Dalam hal sumber daya manusia, Desa Lumbungsari mendirikan BUMDes dan menunjuk beberapa orang yang berasal dari masyarakat biasa, yang artinya bukan merupakan perangkat desa dan BPD. Dalam prosedur perekrutan pengurus atau anggota BUMDes, pemerintah desa menugaskan kepada masing-masing Kepala Dusun untuk merekomendasikan warga masyarakatnya yang memiliki keahlian dan potensi sesuai dengan bidang yang diperlukan dalam membentuk organisasi kepengurusan BUMDes. Jadi, dengan begitu pemerintah desa tidak perlu melakukan pendidikan dan pelatihan terhadap para pengurus BUMDes, sehingga bisa menghemat biaya dan waktu.

Mengenai sumber daya finansial, BUMDes Harapan Jaya memeroleh dana yang berasal dari Dana Desa sebesar Rp.
20.000.000,-. Modal tersebut pada awalnya dirasa kurang oleh para pengurus BUMDes, mereka menghitung itu tidak cukup untuk menangani seluruh kebutuhan dalam menjalankan usaha BUMDes. Ketika dana tersebut digunakan untuk membeli kebutuhan saja, maka tidak ada dana untuk biaya operasional. Namun, setelah memasuki Tahun Anggaran 2018, dan telah mendapatkan dana secara keseluruhan sebesar Rp. 60.000.000,dari Dana Desa, dan sudah bisa memenuhi kebutuhan dan peralatan yang dibutuhkan dalam menjalankan usaha BUMDes ini.

Ketiga, mengenai karakteristik agen pelaksana. Pembahasan pertamanya mengenai organisasi yang terlibat dalam pelaksanaan BUMDes, salah satunya yaitu Badan Permusyawaratan Desa yang juga menjadi agen pelaksana. Respon yang diberikan oleh BPD menunjukkan dukungan yang positif terhadap program BUMDes di Desa Lumbungsari. BPD sebagai salah satu mitra kerja di tingkat desa mendukung penuh program apapun selama tetap sesuai dengan peraturan perundangundangan yang berlaku, dan dengan mengedepankan transparansi agar tidak menimbulkan hal-hal yang tidak diinginkan.

Dalam pelaksanaan programnya, BUMDes harus menghadapi hambatan. Adapun hambatan utama dalam pelaksanaan program ini adalah kecilnya modal dalam pembentukkan BUMDes di Desa Lumbungsari, sehingga cukup sulit untuk mulai menjalankannya. Selain kendala dalam segi finansial, ada juga hambatan yang lain yaitu kurangnya partisipasi masyarakat. Hal ini disebabkan karena sosialisasi yang dilakukan pemerintah desa dan pengurus BUMDes juga masih kurang kepada masyarakat. Hal ini seharusnya bisa diatasi oleh pemerintah desa atau pengurus BUMDes dengan melakukann sosialisasi dalam berbagai cara. Salah satu yang telah dilakukan adalah dengan cara menyampaikan sosialisasi kepada masing-masing Kepala Dusun, dan kemudian diteruskan kepada masing-masing warga masyarakatnya.

Keempat adalah sikap atau kecenderungan para pelaksana. Struktur 
organisasi dan kepengurusan yang jelas merupakan salah satu kunci dalam memenuhi kriteria disposisi yang baik. Begitu pula dengan apa yang telah dilaksanakan oleh BUMDes Harapan Jaya yang telah mengangkat beberapa warga masyarakat desa menjadi pengurus BUMDes. Hal itu dibuktikan dengan diterbitkannya SK Kepala Desa Lumbungsari Nomor 141/Kpts-10/Ds/VII/2016 tentang Pengangkatan Pengurus BUMDesa Lumbungsari.

Terkait dengan penguatan komitmen kelembagaan dalam segi hukum, Desa Lumbungsari mengeluarkan Perdes tantang BUMDes bersamaan dengan dibentuknya BUMDes Harapan Jaya. Demikian halnya dengan prosedur dan mekanisme pengelolaan BUMDes, mereka telah mengikuti sesuai dengan apa yang disampaikan dalam peraturan perundang-undangan yang berada di atasnya.

Satu lagi adalah dukungan dari pemerintah daerah, baik pemerintah kabupaten atau provinsi. Peran pemerintah daerah dalam berjalannya BUMDes Harapan Jaya masih kurang. Adapun pemerintah kabupaten hanya satu tahun sekali melakukan pengawasan dan pembinaan kepada BUMDes Harapan Jaya. Sejauh ini, belum ada bantuan dalam bentuk finansial dari pemerintah daerah untuk melancarkan berjalannya program BUMDes di Desa Lumbungsari. Sedangkan dalam Pasal 14 Permendagri Nomor 39 Tahun 2010 dikatakan bahwa pemerintah daerah dapat memberikan bantuan dalam bentuk dana tugas pembantuan, namun hingga saat ini belum ada bantuan tersebut.

Kelima, komunikasi antar-organisasi dan aktivitas pelaksana. Koordinasi dan jalinan komunikasi telah dilakukan oleh BUMDes Harapan Jaya, baik itu koordinasi dengan pihak yang sama-sama ada di tingkatan desa maupun dengan pihak kecamatan. Mereka melakukan koordinasi terutama dengan BPD terkait, dengan pemerintah desa, TKSK dan Dinas Sosial yang ada di Kecamatan Lumbung. Namun, koordinasi yang dilakukan tidak memiliki waktu yang terjadwal secara khusus, artinya koordinasi dan komunikasi hanya dilakukan ketika diperlukan saja.

Pembahasan terakhir atau keenam adalah lingkungan ekonomi, sosial dan politik. Kondisi ekonomi masyarakat Desa Lumbungsari, mayoritas mata pencahariannya adalah sebagai buruh tani dan petani yang penghasilannya bisa dikatakan pas-pasan. Namun, mereka sebagai sesama pedagang tetap mendukung terhadap adanya BUMDes ini, termasuk para pedagang atau pelaku usaha. Mereka masing-masing menjalankan usahanya secara berdampingan dan saling mendukung, tanpa ada rasa permusuhan diantara sesama pengusaha.

Perubahan yang paling dirasakan oleh masyarakat setelah adanya BUMDes di Desa Lumbungsari adalah dalam bidang jasa unit Laku Pandai. Dimana, masyarakat yang sebelumnya ketika membayar tagihan listrik harus menuju desa lain, kini mereka bisa membayar tagihan listrik di desanya sendiri.

Lingkungan sosial dan politik, dengan adanya BUMDes dari aspek sosial masyarakat pada level desa telah terjadi perubahan paradigma yaitu tumbuhnya jiwa sosial, jiwa kebersamaan terutama tumbuh kesadaran sosial akan pentingnya jiwa entrepreneurship (kewirausahaan) dari warga dan masyarakat desa. Dari aspek politik dengan adanya kebijakan BUMDes yang tidak lepas dari keputusan politik. Keputusan politik berdasarkan kepentingan publik dan masalah publik. Keberhasilan sebuah kebijakan BUMDes tentunya akan menaikan bargaining position dan tentunya reputasi sebuah rezim pada level pemerintahan Desa, demikian pula sebaliknya ketika kebijakan ini gagal atau tidak sukses.

\section{KESIMPULAN}

Implementasi program BUMDes di Desa Lumbungsari Kecamatan Lumbung Kabupaten Ciamis secara umum sudah cukup baik, namun belum optimal. Karena dari awal pembentukkan hingga saat ini, BUMDes Harapan Jaya sedikit demi sedikit mengalami pertumbuhan. Salah satunya yaitu adanya pembangunan sebuah 
gedung kios desa yang diperuntukkan bagi masyarakat yang ingin menyewa untuk membuka usaha. Di samping itu, juga masih ada masalah yang harus diatasi, seperti dalam hal sosialisasi kepada masyarakat. Luasnya wilayah Desa Lumbungsari juga menyebabkan para pelaksana program tidak bisa menjangkau secara keseluruhan, mengingat sumber daya pelaksana yang masih terbatas.

Berdasarkan hasil dari penelitian yang telah dilakukan, saran yang dapat dikemukakan guna mengatasi masalah yang menyangkut permodalan adalah hendaknya BUMDes Harapan Jaya mulai melakukan pengajuan bantuan atau pinjaman, baik itu bekerja sama dengan pihak swasta maupun kepada pihak perbankkan, tentu saja dengan persetujuan dari pihak pemerintah desa terlebih dahulu. Kemudian dalam hal sumber daya manusia, BUMDes Harapan Jaya mungkin sebaiknya melakukan rekrutmen para agenagen/mitra baru, dengan maksud agar dapat menjangkau cakupan yang lebih luas atau bahkan seluruh wilayah Desa Lumbungsari.

\section{DAFTAR PUSTAKA}

Agustino, Leo. (2016). Dasar-Dasar Kebijakan Publik. Bandung: Alfabeta.

Engkus, E. (2013). Desentralisasi (Teori yang Baik dengan Praktek yang buruk), JISPO: Jurnal Ilmu Sosial dan Ilmu Politik, (4), 1-16.

Herdiansyah, Haris. (2012). Metodologi Penelitian Kualitatif untuk Ilmu-ilmu Sosial. Cetakan Ketiga. Jakarta: Salemba Humanika.

Nugroho, Riant. (2003). Kebijakan Publik: Formulasi, Implementasi, dan Evaluasi. Jakarta: Elex Media Komputindo.

Rachmawati, Tutik. (2017). Metode Pengumpulan Data dalam Penelitian Kualitatif. Jurnal. UNPAR PRESS: Bandung.

Senjani, Y. P. (2019). Peran Sistem Manajemen Pada BUMDes dalam Peningkatan Pendapatan Asli Desa. Kumawula: Jurnal Pengabdian Kepada Masyarakat,
2(1), 23-40. $\quad$ Retrieved from http://jurnal.unpad.ac.id/kumawula /article/view/23698/pdf

Subarsono, AG. (2005). Analisis Kebijakan Publik: Konsep, Teori, dan Aplikasi. Yogyakarta: Pustaka Belajar.

Sugiyono. (2012). Metode Penelitian Kuantitatif Kualitatif dan $R \& D$. Bandung: Alfabeta.

Widianingsih, I., Setiawan, H., \& Chuddin, M. (2020). Penguatan Kapasitas Pengelolaan Bumdes Cipta Rahayu Di Desa Cipanjalu Kecamatan Cilengkrang Kabupaten Bandung. Kumawula: Jurnal Pengabdian Kepada Masyarakat, 3(2), 225-238. https://doi.org/10.24198/kumawula.v3i2. 26909

\section{Peraturan perundangan:}

Republik Indonesia. (2014). Undang-Undang Nomor 23 Tahun 2014 tentang Pemerintahan Daerah. Lembaran Negara RI Tahun 2014, Nomor 244. Sekretariat Negara. Jakarta.

Republik Indonesia. (2014). Undang-Undang Nomor 6 Tahun 2014 tentang Desa. Lembaran Negara RI Tahun 2014, Nomor 7. Sekretariat Negara. Jakarta.

Republik Indonesia. (2010). Peraturan Menteri Dalam Negeri Nomor 39 Tahun 2010 tentang Badan Usaha Milik Desa. Berita Negara RI Tahun 2010, Nomor 316. Sekretariat Negara. Jakarta.

Republik Indonesia. (2013). Peraturan Daerah Kabupaten Ciamis Nomor 26 Tahun 2013 tentang Pedoman Tata Cara Pembentukan dan Pengelolaan Badan Usaha Milik Desa. Lembaran Daerah Kabupaten Ciamis Tahun 2013, Nomor 26. Sekretariat Daerah. Ciamis.

Republik Indonesia. (2016). Peraturan Desa Lumbungsari Nomor 7 Tahun 2016 tentang Badan Usaha Milik Desa (BUMDesa). Berita Desa Lumbungsari Tahun 2016, Nomor 07. Sekretariat Desa. Ciamis. 


\section{Media/Online:}

Profil Desa Lumbungsari (2014). Diakses dari:

http://cahayapenge-tahu-

an.blogspot.com/2014/07/profil-desa-

lumbung.html, tanggal 27-11-2020. 